\title{
Growth and development of triticale culture in the Amur Region (Russia)
}

\author{
Aleksey Muratov ${ }^{1, *}$ \\ ${ }^{1}$ Far Eastern State Agrarian University, 86, Politekhnicheskaya str., 675005, Blagoveshchensk, Russia
}

\begin{abstract}
The paper presents the results of studies to determine the optimal density of spring triticale plants at different seeding rates in the southern agricultural zone of the Amur Region (Russia) in order to obtain an optimal grain yield. This crop is new for the Amur Region. It is considered more resistant to stressful weather factors and soil conditions and may become an important link in the production of feed grain in the region. The paper presents the results of field studies of the duration of interfacial periods of spring triticale. The influence of varieties and sowing rates on seedling density and field germination of seeds was determined, as well as the influence of varieties and seeding rates on plant survival. Also, the influence of different seeding rates on grain yield of spring triticale was studied. The paper provides an assessment of dynamics of the average grain yield of spring triticale depending on the seeding rate.
\end{abstract}

\section{Introduction}

The life cycle of plants is divided into phases according to a number of external characteristics. Meteorological conditions affect the speed of plants passing through the developmental phases and the length of the growing season, which have a consistent effect on the productivity of triticale agrocoenosis as a whole (Maltsev V.F. et al., 2002)

In the process of ontogenesis of spring triticale, the dynamics of the development of the onset of phenological phases and stages of orthogenesis, as well as the length of the growing season, is influenced by both the varietal characteristics of the culture and the meteorological conditions of the growing season. Observations of the growth and development of spring triticale plants make it possible to analyze the impact of external factors, varietal characteristics of the culture, and the effect of different seeding rates on the growing season. Even sprouts develop at the same time, which makes harvesting easier and also improves product quality. The prolongation of the growing season leads to uneven development of plants, a decrease in yield and its quality (Chernukha S.A., 20011).

Nowadays, there is little information about the seeding rates of spring triticale, and if we consider that this crop is new for the Amur Region, the study of the terms and methods of harvesting is relevant and requires a comprehensive study. In view of the fact that this culture, unlike other grain crops, is considered more resistant to stressful weather factors

\footnotetext{
*Corresponding author: nic_dalgau@mail.ru
} 
and soil conditions (Tikhonchuk P.V., 2014) and may well become an important link in the production of feed grain in the region.

The aim of the research is to determine the optimal density of spring triticale plants at different seeding rates in the southern agricultural zone of the Amur Region to obtain an optimal grain yield.

\section{Materials and Methods}

Field studies were carried out in 2014-2016 at the Tambov State Variety Testing Site, which is located in the Tambov District of the Amur Region. The trials were established according to the "Methodology of field tests" [Dospekhov B.A., 2014]. The trial establishment was based on a two-factor scheme in 4-fold repetition, where one of the factors was three varieties of spring triticale: Ukro, Carmen, Yarilo, and the other factor was five different seeding rates: 4 million, 5 million, 6 million, 7 million, and 8 million. Plots were placed systematically; accounting area is $25 \mathrm{~m}^{2}$. Sowing was carried out in the third decade of April with the SS-11 "Alpha" selection seeder. Field germination was calculated on two non-adjacent repetitions in the full germination phase, viability immediately before harvesting. The yield was taken into account by the weight method during direct combining with a Sampo-130 combine.

Ukro - created as a result of cooperation of scientists from Russia (Scientific Research Institute of Agriculture of the Central Black Earth Belt named after V.V. Dokuchaev and Voronezh State Agricultural University named after K.D. Glinka) and Ukraine (Plant Production Institute named after V.Ya. Yuriev). The Ukro variety is the first variety of spring triticale created in Russia. Early maturing, the duration of the growing season $74 . . .83$ days.

Carmen - obtained by teams of scientists from the All-Russian Research Institute of Organic Fertilizers and the Vladimir Research Institute of Agriculture. The variety is midseason. The growing season is $76 . . .94$ days. It is distinguished by drought resistance. Tall enough. Purpose: for fodder purposes, for the production of grain fodder and grain silage.

Yarilo - obtained by the team of the Krasnodar Research Institute of Agriculture named after P.P. Lukyanenko. Plant height $65 \ldots 91 \mathrm{~cm}$. Resistant to lodging. The growing season is $88 \ldots 96$ days. Used for cultivation for feed grains and fodder grass.

The predecessor is the traditional culture for our region - soybeans, the technology of soil preparation - energy-saving. It included the following tillage: in the fall - disking with a disc harrow, in the spring - harrowing in two tracks.

Agrometeorological conditions were contrasting, but favorable for the cultivation of spring triticale. The most favorable precipitation and temperature regime for the growth and development of spring triticale was observed in 2014 and 2016, 2015 was characterized as arid.

\section{Results}

As can be seen from Table 1, the duration of the whole life cycle and the growing season of spring triticale varied depending on the weather conditions that disappeared during the field period. The life cycle of spring triticale from sowing to harvesting varied from 106 to 107 days over the years of study, and the growing season from germination to full ripeness was 90 to 95 days.

The duration of the "sowing - germination" period in our studies was not the same over the years and depended mainly on weather conditions. In 2014 and 2015, there was not a big difference, which was only two days, but in 2016 the difference with previous years 
was 16 days. The longest period from sowing to germination was observed in the third year of study - 23 days, the duration of the period in this year is explained by the climatic features of spring, low temperatures in the second and third decades of April and early May, lack of soil moisture during this period, and strong winds.

Table 1. Duration of interfacial periods of spring triticale, days.

\begin{tabular}{|l|c|c|c|c|}
\hline \multicolumn{1}{|c|}{ Interphase period } & 2014 & 2015 & 2016 & $\begin{array}{c}\text { Average for } \\
2014-2016\end{array}$ \\
\hline Sowing - seedlings & 14 & 16 & 23 & 18 \\
\hline $\begin{array}{l}\text { Seedlings - } \\
\text { tillering }\end{array}$ & 15 & 17 & 16 & 16 \\
\hline $\begin{array}{l}\text { Tillering - stem } \\
\text { elongation }\end{array}$ & 17 & 16 & 17 & 17 \\
\hline $\begin{array}{l}\text { Stem elongation - } \\
\text { earing }\end{array}$ & 18 & 16 & 17 & 42 \\
\hline Earing - ripeness & 42 & 41 & 45 & 92 \\
\hline $\begin{array}{l}\text { Seedlings - } \\
\text { ripeness }\end{array}$ & 92 & 90 & 95 & 106 \\
\hline Sowing-harvesting & 106 & 106 & 107 & \\
\hline
\end{tabular}

In subsequent periods, for all years of research, the fluctuation was 1-2 days and interphase periods took place in 15-17 days. This is due to the fact that there were favorable agrometeorological conditions: the optimal ratio of precipitation and temperatures.

The longest period of earing-ripeness was: it was 42 days in 2014, it was approximately the same in 2015 - 41 days. In 2016, this period was 45 days. Just like the period of sowingseedlings, it was the longest due to climatic features of the year.

The development of any agrocoenosis, as well as a natural phytocoenosis, is largely determined by the competition of its representatives for the effective use of environmental factors. However, if competition plays a positive role in nature, contributing to survival, then in agrocoenosis it leads to a variety of plant development, and, as a consequence, to a decrease in the overall productivity of sowing and a noticeable deterioration in the quality of the products obtained. This phenomenon can be largely eliminated by the optimal distribution of plants over the area of the field, achieved by using different seeding rates (Yurchenko E.A., 2002).

The seedling density is the first indicator of the yield structure that can be assessed visually. On its basis, it is possible to conduct a survey of fields, paying attention to the uniformity and friendship of the emergence of seedlings. The optimal seedling density of grain crops should be considered 400-500 plants per $1 \mathrm{~m}^{2}$ at a seeding rate of 6 million germinating seeds per hectare, while the germination rate is at the level of $70-80 \%$ (Kukonkova A.A., 2013).

Field germination of seeds and survival of plants are one of the most important indicators, since the yield of a given crop largely depends on the planting density before harvesting.

The optimal plant density providing the highest yield result is determined by a favorable combination of the average productivity of one plant per unit area. At low seeding rates, the planting density is thinned and, in addition, weeds get more opportunities for developing. At overestimated rates, the sowings are thickened and the productivity of the ear sharply decreases. In both cases, the yield decreases.

Over the years of the study, the seedling density and field germination varied significantly, both in seeding rates and in varieties.

As can be seen from Table 2, in 2014, the highest seedling density was in the triticale variety Yarilo at a seeding rate of 8 million units/ha. With a decrease in the seeding rate, 
field germination slightly increased. The lowest was at 7 million germinating seeds. In the Ukro variety, on the contrary, the highest field germination was at a minimum rate of 4 million germinating seeds $(98.7 \%)$. With an increase in the seeding rate, the density of seedlings decreased. But the smallest one was in the Carmen variety for all variants. It did not exceed $75.2 \%$.

Table 2. Influence of varieties and sowing rates on seedling density and field germination of seeds.

\begin{tabular}{|c|c|c|c|c|c|c|c|c|c|}
\hline \multirow{3}{*}{ Varieties } & \multirow{3}{*}{$\begin{array}{l}\text { Seeding } \\
\text { rates }\end{array}$} & \multicolumn{4}{|c|}{ Seedling density, $\mathrm{pcs} / \mathrm{m}^{2}$} & \multicolumn{4}{|c|}{ Field germination, $\%$} \\
\hline & & \multicolumn{3}{|c|}{ years } & \multirow{2}{*}{$\begin{array}{c}\text { average } \\
\text { for } \\
2014 \text { - } \\
2016\end{array}$} & \multicolumn{3}{|c|}{ years } & \multirow{2}{*}{$\begin{array}{c}\text { average } \\
\text { for } \\
2014- \\
2016\end{array}$} \\
\hline & & 2014 & 2015 & 2016 & & 2014 & 2015 & 2016 & \\
\hline \multirow[t]{5}{*}{ Yarilo } & $4 \mathrm{mln}$ & 395 & 298 & 308 & 333 & 98.7 & 74.5 & 77.0 & 83.4 \\
\hline & $5 \mathrm{mln}$ & 480 & 408 & 378 & 422 & 96.0 & 81.6 & 75.6 & 84.4 \\
\hline & $6 \mathrm{mln}$ & 543 & 427 & 455 & 475 & 90.5 & 71.2 & 75.8 & 79.2 \\
\hline & $7 \mathrm{mln}$ & 684 & 495 & 555 & 578 & 97.7 & 70.7 & 79.8 & 82.6 \\
\hline & $8 \mathrm{mln}$ & 793 & 550 & 579 & 640 & 99.1 & 68.7 & 72.4 & 80.1 \\
\hline \multirow[t]{5}{*}{ Ukro } & $4 \mathrm{mln}$ & 373 & 325 & 259 & 319 & 93.2 & 81.2 & 64.7 & 79.7 \\
\hline & $5 \mathrm{mln}$ & 422 & 389 & 347 & 386 & 84.4 & 77.8 & 69.0 & 77.1 \\
\hline & $6 \mathrm{mln}$ & 467 & 432 & 422 & 440 & 77.8 & 72.0 & 70.3 & 73.4 \\
\hline & $7 \mathrm{mln}$ & 527 & 523 & 469 & 506 & 75.3 & 74.7 & 67.0 & 72.3 \\
\hline & $8 \mathrm{mln}$ & 606 & 583 & 534 & 574 & 75.7 & 72.9 & 66.7 & 71.8 \\
\hline \multirow[t]{5}{*}{ Carmen } & $4 \mathrm{mln}$ & 291 & 229 & 285 & 292 & 72.7 & 74.7 & 71.2 & 72.9 \\
\hline & $5 \mathrm{mln}$ & 341 & 357 & 334 & 344 & 68.2 & 71.4 & 66.8 & 68.8 \\
\hline & $6 \mathrm{mln}$ & 441 & 411 & 429 & 427 & 73.5 & 68.5 & 71.5 & 71.2 \\
\hline & $7 \mathrm{mln}$ & 450 & 469 & 484 & 467 & 64.3 & 67.0 & 69.1 & 66.8 \\
\hline & $8 \mathrm{mln}$ & 602 & 476 & 564 & 547 & 75.2 & 59.5 & 70.5 & 68.4 \\
\hline \multicolumn{2}{|c|}{ LSD } & 43 & 33 & 47 & - & - & - & - & - \\
\hline \multicolumn{2}{|c|}{ LSDa } & 19 & 15 & 21 & - & - & - & - & - \\
\hline \multicolumn{2}{|c|}{ LSDb } & 25 & 19 & 27 & - & - & - & - & - \\
\hline
\end{tabular}

In 2015 , the change in the seedling density by varieties was repeated. As in 2014, the change in the seedling density according to the norms increased from the maximum seeding rate to the minimum.

In 2016, the minimum planting density was observed in the Ukro variety, the highest in the Yarilo variety. The change in the planting density according to the variants for the Yarilo variety was the following: largest at a seeding rate of 7 million viable seeds $(79.8 \%)$, the minimum at 8 million viable seeds $(72.4 \%)$. For the Carmen variety, with a small difference, field germination varied according to variants from $66.8 \%$ at a seeding rate of 5 million to $71.5 \%$ at 6 million viable seeds per hectare. For the Ukro variety, field germination increased from the minimum seeding rate $(64.7 \%)$ to the variant of 6 million viable seeds $(70.3 \%)$; with a subsequent increase in the seeding rate, the planting density decreased.

On average, over three years of research, the highest germination density for all variants of the test from the studied varieties had the Yarilo spring triticale variety, the highest value of field germination was at a rate of 4-5 million germinating seeds per hectare. When considering other varieties, it can also be seen that the highest value of the field germination indicator is observed at seeding rates of no more than 6 million germinating seeds per hectare, $71.2-84.4 \%$.

To create the optimal density of productive planting, the seeding rate in each specific case must be adjusted taking into account a large number of varying factors (agro-climatic 
conditions, agricultural technology, varieties, quality of seed material and crop culture). An indicator that integrates the influence of many factors is the overall survival of plants or, in other words, the ratio of the number of plants survived to harvesting to the number of seeds sown on the same area (Saulin A.A., 2010).

In our experiments, the survival rate of spring triticale plants differed sharply over the years of study and varied from $40.2 \%$ to $79.3 \%$. The greatest influence on this indicator was exerted by weather conditions during the growing season (Table 3 ).

In 2014, plant survival was at the highest level and varied from a minimum of $53.9 \%$ for the Carmen variety at a rate of 8 million germinating seeds to a maximum of $79.3 \%$ for the Yarilo variety at a rate of 7 million germinating seeds.

Table 3. Influence of varieties and seeding rates on plant survival.

\begin{tabular}{|c|c|c|c|c|c|c|c|c|c|}
\hline \multirow{3}{*}{$\begin{array}{l}\text { Varieties } \\
\text { (factor a) }\end{array}$} & \multirow{3}{*}{$\begin{array}{c}\text { Seeding } \\
\text { rates } \\
\text { (factor } \\
\text { b) }\end{array}$} & \multicolumn{4}{|c|}{$\begin{array}{l}\text { Viability of plants before } \\
\text { harvesting, } \mathrm{pcs} / \mathrm{m}^{2}\end{array}$} & \multicolumn{4}{|c|}{$\begin{array}{c}\text { Survival of plants before } \\
\text { harvesting, } \%\end{array}$} \\
\hline & & \multicolumn{3}{|c|}{ years of research } & \multirow{2}{*}{$\begin{array}{c}\text { average } \\
\text { for } \\
2014- \\
2016 \\
\end{array}$} & \multicolumn{3}{|c|}{ years of research } & \multirow{2}{*}{$\begin{array}{c}\text { average } \\
\text { for } \\
2014- \\
2016 \\
\end{array}$} \\
\hline & & 2014 & 2015 & 2016 & & 2014 & 2015 & 2016 & \\
\hline \multirow{5}{*}{ Yarilo } & $4 \mathrm{mln}$ & 277 & 251 & 250 & 259 & 69.2 & 62.7 & 62.5 & 64.8 \\
\hline & $5 \mathrm{mln}$ & 305 & 255 & 318 & 292 & 61.0 & 51.0 & 63.6 & 58.5 \\
\hline & $6 \mathrm{mln}$ & 401 & 321 & 408 & 377 & 66.8 & 53.5 & 68.0 & 62.9 \\
\hline & $7 \mathrm{mln}$ & 555 & 308 & 520 & 461 & 79.3 & 44.0 & 74.3 & 65.9 \\
\hline & $8 \mathrm{mln}$ & 495 & 347 & 480 & 441 & 62.1 & 43.4 & 60.0 & 55.2 \\
\hline \multirow{5}{*}{ Ukro } & $4 \mathrm{mln}$ & 280 & 235 & 207 & 240 & 70.0 & 58.7 & 51.7 & 60.0 \\
\hline & $5 \mathrm{mln}$ & 323 & 278 & 273 & 291 & 64.6 & 55.6 & 54.6 & 58.3 \\
\hline & $6 \mathrm{mln}$ & 359 & 311 & 324 & 331 & 59.8 & 51.8 & 54.0 & 55.2 \\
\hline & $7 \mathrm{mln}$ & 457 & 403 & 394 & 418 & 65.3 & 57.6 & 56.3 & 59.7 \\
\hline & $8 \mathrm{mln}$ & 458 & 370 & 458 & 429 & 57.2 & 46.2 & 57.2 & 53.5 \\
\hline \multirow{5}{*}{ Carmen } & $4 \mathrm{mln}$ & 262 & 275 & 205 & 247 & 65.5 & 68.7 & 51.2 & 61.8 \\
\hline & $5 \mathrm{mln}$ & 314 & 250 & 252 & 272 & 62.8 & 50.0 & 50.4 & 54.4 \\
\hline & $6 \mathrm{mln}$ & 357 & 233 & 318 & 303 & 59.5 & 38.8 & 53.0 & 50.0 \\
\hline & $7 \mathrm{mln}$ & 417 & 318 & 357 & 364 & 59.3 & 45.4 & 51.0 & 51.9 \\
\hline & $8 \mathrm{mln}$ & 431 & 322 & 451 & 401 & 53.9 & 40.2 & 56.4 & 50.2 \\
\hline \multicolumn{2}{|c|}{ LSD } & 36 & 32 & 51 & - & - & - & - & - \\
\hline \multicolumn{2}{|c|}{ LSDa } & 16 & 14 & 23 & - & - & - & - & - \\
\hline \multicolumn{2}{|c|}{ LSDb } & 21 & 18 & 29 & - & - & - & - & - \\
\hline
\end{tabular}

The lowest survival rates of spring triticale plants over the years of research were obtained in 2015 . The lowest survival rate was noted in the Carmen variety, $38.8 \%$ at a rate of 6 million germinating seeds. In general, the same pattern as in 2014 was observed.

In 2016, the Yarilo variety had the highest survival rates, both by varieties and by seeding rates (up to $74.3 \%$ ). In varieties Ukro and Carmen, the survival rate of plants before harvesting was mostly stable and did not exceed $56.4 \%$.

On average, for 2014-2016, the highest plant survival rate was observed in the Yarilo variety of $65.9 \%$ at a rate of 7 million germinating seeds, as well as for the variety as a whole. The percentage of survival in varieties Ukro and Carmen varied almost stably from a minimum of $50.4 \%$ to a maximum of $57.2 \%$. A general pattern can be seen for all varieties - the minimum survival rate at the maximum seeding rate and, with a decrease in the seeding rate, an increase in survival rate, with the exception of partial differences.

The yield of triticale, like that of other grain crops, is largely determined by the planting density, which in turn depends on weather conditions (Ruzanov A.Yu., 2010; Gerasimov 
S.A., 2015). In our experiments, the grain yield of spring triticale varied over the years and variants (Table 4).

In 2014, the maximum yield when assessing various seeding rates was observed in all varieties in the variant with the highest seeding rate. Apparently, this was due to the conditions of the year (the low level of moisture supply: hydrothermal index was 0.51 in the summer period). In the context of varieties, the highest yield was observed in the spring triticale variety Yarilo (30.8-32.4 c/ha), in the Carmen variety, the maximum yield reached $31.0 \mathrm{c} / \mathrm{ha}$, and in the Ukro variety $-29.4 \mathrm{c} / \mathrm{ha}$. At the same time, this year was characterized by the best grain yield in terms of all the years of observation, which is once again confirm the biological peculiarity of spring triticale to give high indicators of productivity with a lack of moisture.

Table 4. Influence of different seeding rates on grain yield of spring triticale, c/ha.

\begin{tabular}{|c|c|c|c|c|}
\hline $\begin{array}{l}\text { Seeding rate, mln } \\
\text { viable seeds/ha }\end{array}$ & 2014 & 2015 & 2016 & $\begin{array}{l}\text { Average for } \\
2014-2016\end{array}$ \\
\hline \multicolumn{5}{|c|}{ Ukro } \\
\hline 4 & 27.2 & 28 & 23.4 & 26.2 \\
\hline 5 & 28.5 & 28.2 & 23.1 & 26.6 \\
\hline 6 & 28.9 & 29 & 25 & 27.6 \\
\hline 7 & 29.2 & 29 & 24.7 & 27.6 \\
\hline 8 & 29.4 & 28.3 & 25.5 & 27.7 \\
\hline \multicolumn{5}{|c|}{ Yarilo } \\
\hline 4 & 30.8 & 28.8 & 28.6 & 29.4 \\
\hline 5 & 31.3 & 29.4 & 29.1 & 29.9 \\
\hline 6 & 31.9 & 28.5 & 32.1 & 30.8 \\
\hline 7 & 31.6 & 28 & 29.8 & 29.8 \\
\hline 8 & 32.4 & 26.4 & 29.3 & 29.4 \\
\hline \multicolumn{5}{|c|}{ Carmen } \\
\hline 4 & 26.3 & 28.1 & 21.9 & 25.4 \\
\hline 5 & 29.3 & 29.3 & 23.7 & 27.4 \\
\hline 6 & 28.9 & 29.9 & 27.5 & 28.8 \\
\hline 7 & 30.3 & 29 & 26.9 & 28.7 \\
\hline 8 & 31.0 & 28.6 & 24.6 & 28.1 \\
\hline $\mathrm{LSD}_{05}$ & 2.2 & 1.3 & 2.6 & - \\
\hline $\mathrm{LSD}_{\mathrm{A}}$ & 1.0 & 0.6 & 1.2 & - \\
\hline $\mathrm{LSD}_{\mathrm{B}}$ & 1.2 & 0.8 & 1.5 & - \\
\hline Aver. error & 0.8 & 0.5 & 0.9 & - \\
\hline Diff. error & 1.1 & 0.7 & 1.3 & - \\
\hline
\end{tabular}

In 2015, the yield of triticale varieties did not differ significantly across varieties. According to the seeding rate, it was maximum for the Ukro variety in the variant of 6-7 million pcs/ha and amounted to $29.0 \mathrm{c} / \mathrm{ha}$, for the Yarilo variety - in the variant of 5 million $\mathrm{pcs} / \mathrm{ha}-29.4 \mathrm{c} / \mathrm{ha}$, for the Karmen variety - in the variant of 6 million pcs/ha $-29.9 \mathrm{c} / \mathrm{ha}$. At the same time, the average yield for the variants of the experiment did not fluctuate significantly and was noted at the level of 28.2-29.0 c/ha.

In 2016, on average for the variety, there was a clear dependence of the increase in yield on the lowest seeding rate -4 million pcs/ha to 6 million pcs/ha, and with a further increase in the seeding rate, the yield of spring triticale grain decreased. In terms of varieties, the highest yield was in the Yarilo variety $(32.1 \mathrm{c} / \mathrm{ha})$, for the Carmen and Ukro varieties, the highest yield reached 27.5 and $25.5 \mathrm{c} /$ ha, respectively. 
On average for 2014-2016, the spring triticale variety Yarilo had the maximum grain yield of $30.8 \mathrm{c} / \mathrm{ha}$; the highest yield of the Ukro and Carmen varieties reached 27.7 and 28.8 c/ha.

According to the seeding rates, the yield dominated at the sowing of 6 million viable seeds per hectare. When considering particular differences, it can be noted that regardless of the conditions of the year, the lowest yield was observed in the variant with the lowest seeding rate. At the same time, if we take the seeding rate of 6 million pieces/ha as a reference, then the difference in grain yield between the minimum and maximum rates was 9.4 and $0.3 \%$ for the Ukro variety, respectively, for the Yarilo variety $-4.5 \%$, respectively, and for the Carmen variety -11.8 and $2.4 \%$, respectively.

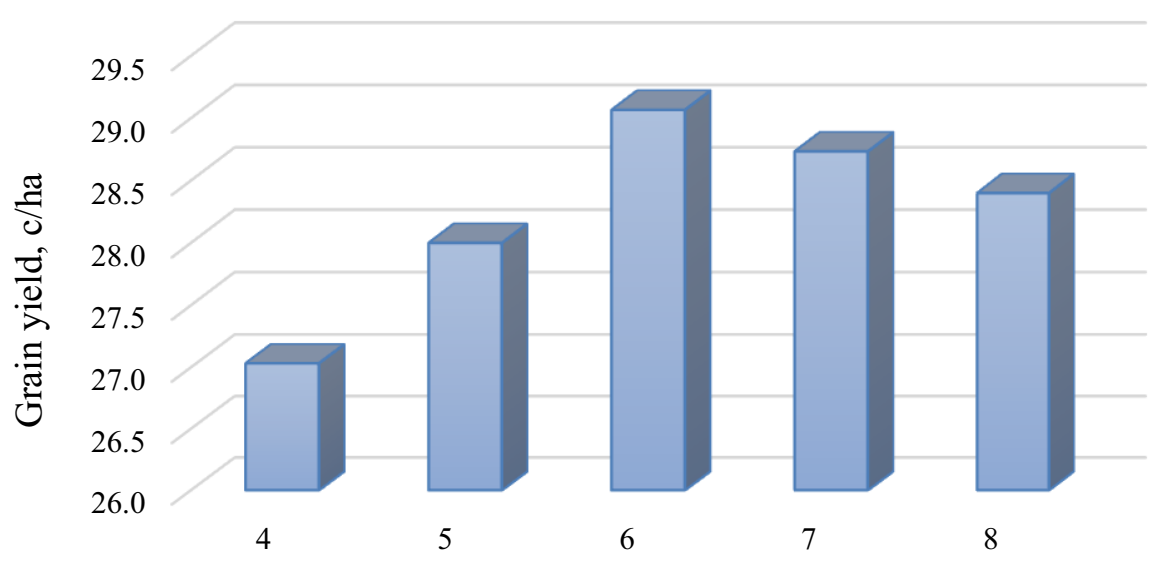

Seeding rate, mln pcs/ha

Fig. 1. Dynamics of the average grain yield of spring triticale depending on the seeding rate, (average for 2014-2016).

As shown in Figure 1, with respect to the change in the yield of spring triticale depending on the seeding rate, it was found that, according to the averaged data for all studied varieties, the maximum yield value is achieved at a seeding rate of 6 million pcs/ha. At the same time, an increase in the seeding rate by 1 million viable seeds per hectare (from 4 to 6 million pieces) lead to an increase of $1 \mathrm{c} / \mathrm{ha}$, a subsequent increase in the seeding rate (from 6 to 8 million pieces) led to a decrease in yield by $0.3 \mathrm{c} / \mathrm{ha}$. When calculating pair correlation, the indicator at a rate of 4 to 6 million pcs/ha is 0.5 , and with an increase in the rate from 6 to 8 million $\mathrm{pcs} / \mathrm{ha}$, it decreases to 0.3 .

As a result, it can be concluded that the most optimal seeding rate under the conditions of the Amur Region is 6 million viable seeds per hectare.

\section{References}

1. V. F. Maltsev, M. K. Kayumov The system of biologization of agriculture in the NonBlack Earth Zone of Russia. Under the editorship of Honored Scientists of the Russian Federation, doctors of agricultural sciences, professors (Part II) (M.: FGNU "Rosinformagrotech") 576 (2002)

2. S. A. Chernukha S A Responsiveness of varieties of spring soft wheat to seeding rates and biologically active substances in the Volgograd Trans-Volga region: dissertation...Candidate of Agricultural Sciences, 260 (2011) 
3. P. V. Tikhonchuk, A. A. Muratov,N. S. Shmatok Achievements of science and technology of the agricultural sector 28(12), 40, (2014)

4. B. A. Dospekhov Method of field experiment (with the basics of statistical processing of research results) textbook 351 (2014)

5. E. A. Yurchenko Productivity of buckwheat depending on the methods of sowing, seeding rates and fertilizers on the southern chernozems of the Saratov Right Bank: dissertation 219 (2002)

6. Kukonkova Formation of the harvest of spring triticale depending on the seeding rates and herbicides in the conditions of light gray forest soil in the southeast of the VolgaVyatka region: dissertation 180 (2013)

7. A. Saulin Formation of productivity of varieties of barley at different seeding rates on leached chernozems of the south of the forest-steppe of the Non-Black Earth Region: dissertation. 165 (2010)

8. A Yu Ruzanov A Yu Rational terms and sowing rates of semi-intensive winter wheat varieties on autumn fallow on the southern chernozem of the Volgograd region: dissertation, 242 (2010)

9. S. A. Gerasimov, N. E. Lyakhova Vestnik of Kemerovo State University 1(61)-2 11 (2015) 